\title{
Kinetics and Thermodynamics of Peppermint Oil Extraction from Peppermint Leaves
}

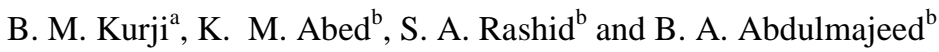

${ }^{a}$ Chemical and petrochemical Engineering department -College of Engineering-University of Anbar - Iraq

${ }^{b}$ Chemical Engineering department - College of Engineering.-University of Baghdad - Iraq

\begin{abstract}
This work aims to study extraction of essential oil (EO) from peppermint leaves using hydro-distillation methods. The peppermint oil extraction with hydro-distillation method studied the effect of the extraction temperature on the yield of peppermint oil. Besides, it also studied the kinetics during the extraction process. The second-order mechanism was adopted in the model of hydro-distillation to estimate many parameters such as the initial extraction rate, capacity of extraction, the constant rat of extraction at various temperatures and activation energy. The results showed that the extraction process is a spontaneous process, since the Gibbs free energy has a negative value at all studied temperatures. For example the Gibbs free energy at $\left(70,80,90\right.$, and $\left.100{ }^{\circ} \mathrm{C}\right)$ were $(-2.93$, $3.84,-4.75,-5.66)$ respectively.
\end{abstract}

Keywords: hydro-distillation, Arrhenius equation, entropy change, enthalpy change, Gibbs free energy, Peppermint leaves

Received on 08/09/2019, Accepted on 15/10/2019, published on 30/12/2019

https://doi.org/10.31699/IJCPE.2019.4.1

\section{1- Introduction}

An EO is a concentrated hydrophobic liquid containing volatile aromatic compounds from plants [1]. Essential oils are also known as etheric oils or oil fly [2]. EO is generally derived from one or more plant parts, such as flowers, leaves, stems, bark, wood, roots and seeds [3]. EO is a mixture of saturated and unsaturated hydrocarbons, alcohol, aldehydes, esters, ethers, ketones, oxides, phenols and terpenes that may produce characteristics [4]. Essential oils are generally colorless to slightly yellowish and only slightly soluble in water and dissolve fairly well in an organic solvent and mix very well with vegetable oils and fats. Many essential oils have antibacterial, anti-fungal, and antiparasitic properties [5],[6].

One of the most particular source of plant containing EO is peppermint. Peppermint belongs to the family of Lamiaceae [4]. Peppermint oil is derived from the peppermint plant, a cross between water mint and spearmint, which is indigenous to Europe and North America but now grown throughout the world [7]. Peppermint oil has been widely used as flavoring in foods, beverage, as a fragrance in soaps, cosmetics, health and tobacco industries [4,7]. The Food and Drug Administration lists peppermint and peppermint oil as "generally recognized as safe", [8], [9]. Chemically, the major constituents of the peppermint oil include the terpenes, menthol, menthone, isomenthone, menthyl acetate, menthofuran and 1,8-cineol[7,8]. Peppermint can be used in the medicinal preparations and as a flavoring agent in foods and confectionery [8].
There are several methods can be used for extracting essential oils such as expression and organic solvent distillation processes. However, hydro-distillation is one of the commonly used for several advantages such as simplicity and non-solvent involvement [10],[11],[12]. The purpose of this research is to study the process of oil extraction from peppermint leaves using a hydrodistillation method. In this research, the effect of temperature to the yield of peppermint oil and kinetics during the extraction process based on a second-order extraction model will be studied. Then, studying of the methods for determining the initial extraction rate and the saturated extraction capacity will be conducted. In addition, the energetic aspect of the EO extraction will be studied. The current work presents first tempt to study the parameters of thermodynamic using this type of EO. Then, Arrhenius equation parameters will be estimated at different temperature.

\section{2- Materials and Methods}

\subsection{Experimental Work}

Leaves of the peppermint plants were collected from a local market. The leaves were dried in shade for ten days, and then it was crashed. Twenty gram of peppermint leaves were introduced to Pyrex extraction flask with 400 $\mathrm{ml}$ of distilled water. The flask is equipped with electrical stirrer at $100 \mathrm{rpm}$. A water bath was used to control the extraction temperature. The extraction of peppermint oil was conductedat different temperature $(343 \mathrm{k}, 353 \mathrm{k}, 363 \mathrm{k}$ and $373 \mathrm{k})$. 
The process continued until the equilibrium was reached. Then, the peppermint oil was collected and stored at laboratory conditions. Fig. 1 shows a schematic diagram of the experimental setup. The concentration of EO was calculated by multiple the volume of EO by the density of oildivided by the total volume of solvent.

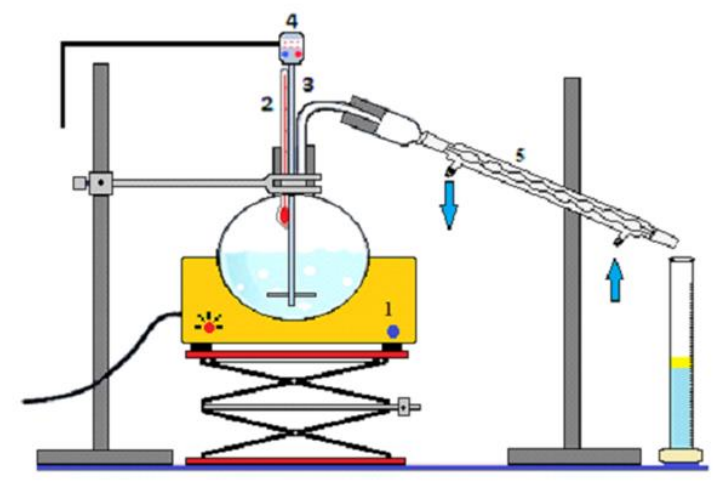

Fig. 1. Schematic diagram of the hydro-distillation setup: 1; Water bath, 2; thermometer, 3;stirrer, 4; Electric motor and 5 ; condenser

\subsection{Kinetic Model of Peppermint Oil Extraction}

The second-order extraction kinetics model, is a commonly used model for the solid-liquid-extraction process, was chosen in the present work.

$\frac{d C_{t}}{d_{t}}=k_{r}\left(C_{s}-C_{t}\right)^{2}$

Where: $\mathrm{kr}\left(\mathrm{Lg}^{-1} \mathrm{~m}^{-1}\right)$ is rate constant for $2^{\text {nd }}$-order model, Cs $\left(\frac{\mathrm{g}}{\mathrm{L}}\right)$ is the concentration of essential oil at saturation (extraction capacity) and $\mathrm{C}_{\mathrm{t}}\left(\frac{\mathrm{g}}{\mathrm{L}}\right)$ is the concentration of peppermint oil at any time $\mathrm{t}(\mathrm{min})$.

By grouping variables, equation (2) is obtained:

$\frac{d C_{t}}{\left(C_{s}-C_{t}\right)^{2}}=k_{r} d t$

The boundary conditions aret $=0, \mathrm{Ct}=0$ and $\mathrm{Ct}$ at timet . Integrating the rate equation for a $2^{\text {nd }}$-order extraction gave equation (3):

$C_{t}=\frac{C_{s}^{2} k_{r} t}{1+C_{s} k_{r} t}$

Rearrangeequation (3) to get equation (4):

$\frac{\mathrm{t}}{\mathrm{C}_{\mathrm{t}}}=\frac{1}{\mathrm{k}_{\mathrm{r}} \mathrm{C}_{\mathrm{S}}^{2}}+\frac{\mathrm{t}}{\mathrm{C}_{\mathrm{S}}}$

By rearrange equation (4), the rate of extraction (equation 5) can be written as:

$\frac{\mathrm{C}_{\mathrm{t}}}{\mathrm{t}}=\frac{1}{\left(1 / \mathrm{k}_{\mathrm{r}} \mathrm{C}_{\mathrm{S}}^{2}\right)+\left(\mathrm{t} / \mathrm{C}_{\mathrm{S}}\right)}$

When $\mathrm{t}$ approaches 0 the initial extraction rate, hi, as $\frac{\mathrm{t}}{\mathrm{C}_{\mathrm{t}}}$, can be written as equation (6): $\mathrm{hi}=\mathrm{k}_{\mathrm{r}} \mathrm{C}_{\mathrm{S}}^{2}$

At any time, the concentration of peppermint oil can be expressed as:

$\mathrm{C}_{\mathrm{t}}=\frac{\mathrm{t}}{(1 / \mathrm{hi})+\left(\mathrm{t} / \mathrm{C}_{\mathrm{S}}\right)}$

Equation(3) can be rearranged to be as shown in equation (8):

$\frac{\mathrm{t}}{\mathrm{C}_{\mathrm{t}}}=\frac{1}{\mathrm{hi}}+\frac{\mathrm{t}}{\mathrm{C}_{\mathrm{S}}}$

By plotting experimental values of $\frac{t}{C_{t}}$ versus $t$, the values of the initial extraction rate hi, the saturation concentration addition to the constant of $2^{\text {nd }}$-order extraction rate, can be determined using both the slope and intercept.

\subsection{Activation energy}

Arrhenius equation is given by equation (9), where it can be used for kinetics study.

$\mathrm{k}_{\mathrm{r}}=\mathrm{A} \exp \left(-\mathrm{E}_{\mathrm{A}} / \mathrm{RT}\right)$

Where: $\mathrm{k}_{\mathrm{r}}\left(\frac{\mathrm{L}}{\mathrm{g} \min }\right)$, the extraction rate constant, $\mathrm{T}(\mathrm{K})$ is the absolute temperature of extraction process, $\mathrm{R}$ $\left(3.814 \frac{\mathrm{J}}{\mathrm{mol} \mathrm{K}}\right)$ is gas constant, $\mathrm{A}\left(\frac{\mathrm{L}}{\mathrm{g} \mathrm{min}}\right)$ is Arrhenius factor and $\mathrm{E}_{\mathrm{A}}\left(\frac{\mathrm{KJ}}{\mathrm{mol}}\right)$ is activation energy of extraction.

Equation (10), a linear relationship between $\mathrm{k}_{\mathrm{r}}$ and $\frac{1}{\mathrm{~T}}$ can be obtained from equation (9).

$\ln \mathrm{k}_{\mathrm{r}}=\ln \mathrm{A}+\left(\frac{-\mathrm{E}_{\mathrm{A}}}{\mathrm{R}}\right) \frac{1}{\mathrm{~T}}$

Where: the Arrhenius equation constants, $\mathrm{A}$ and $\mathrm{k}_{\mathrm{r}}$ are known for the extraction process, while $E_{A}$ can be calculated.

\subsection{Thermodynamic parameters}

Thermodynamic parameters for the extraction of peppermint oil were estimated using Van't Hoff equation [1]:

$\ln K_{e}=\frac{-\Delta G^{0}}{R} \frac{1}{T}=\frac{-\Delta H^{0}}{R} \frac{1}{T}+\frac{\Delta S^{0}}{R}$

$\Delta \mathrm{G}^{0}=\Delta \mathrm{H}^{0}-\mathrm{T} \cdot \Delta \mathrm{S}^{0}$

Where: $\mathrm{K}_{\mathrm{e}}$ is equilibrium constant, $\mathrm{T}(\mathrm{K})$ is absolute temperature of extraction process, $\mathrm{R}$ is gas constant, $\Delta \mathrm{G}^{0}$, $\left(\frac{\mathrm{KJ}}{\mathrm{mol}}\right)$ is Gibbs free energy, $\Delta \mathrm{H}^{0},\left(\frac{\mathrm{KJ}}{\mathrm{mol}}\right)$ is extraction enthalpy and $\Delta S^{0}\left(\frac{\mathrm{J}}{\mathrm{mol} \mathrm{K}}\right)$ is extraction entropy. Enthalpy and entropy can be calculated via plottingln $\mathrm{K}_{\mathrm{e}} \mathrm{vs} \frac{1}{\mathrm{~T}}$. 


\section{3- Results And Discussions}

\subsection{Effect of Extraction Temperature}

Fig. 2 shows influence of temperature on extraction of peppermint oil. The effect of extraction temperature on the peppermint oil extraction kinetics was studied from 70 to $100{ }^{\circ} \mathrm{C}$. Increasing the temperature of extraction increases peppermint oil yield.For each temperature, the rate of extraction started with sharply increase more than afterwards.

The final concentration of EO was increased when the extraction temperature increased as shown Fig. 2 This is because the higher temperature increases the rate of peppermint extraction (evaporation) and the diffusion of the peppermint oil during the process becomes faster [2],[13],[14],[15],[16],[17]. The different concentrations between the peppermint leaves and water phase represent a driving force for the diffusion of soluble oils according to the fundamentals of mass transfer between the phases (Fick's law). The mass transfer rate, then, reaches a zero when the equilibrium state is occurred. In fact, the dissolution process and diffusion process are dominated in the extraction of the EO according to the different concentrations between the solid phase and bulk liquid phase [18].

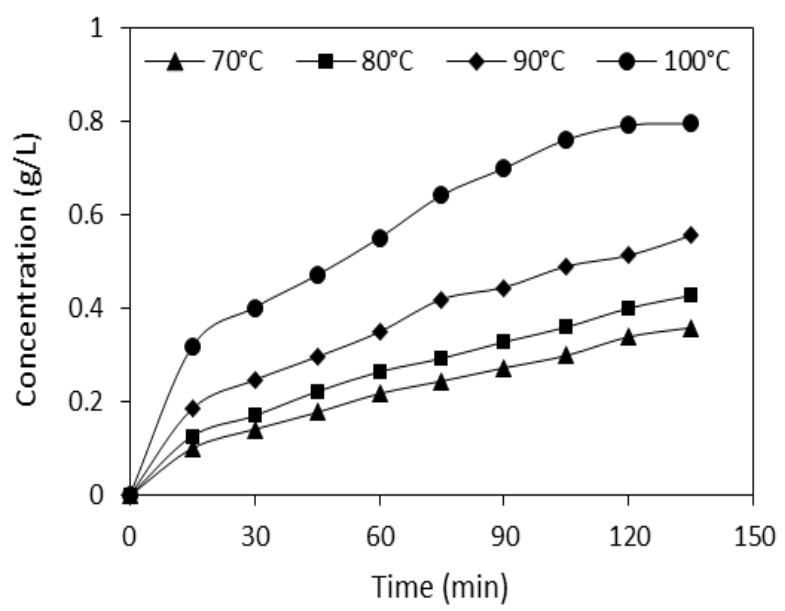

Fig. 2. Influence of temperature on the concentration of peppermint oil

\subsection{Kinetics of Peppermint Oil Distillation}

Peppermint oil extraction process occurs in two successive stages: (i) dissolution and scrubbing process can be created by the fresh solvent (as driving force); (ii) then external diffusion of peppermint oil into the extract giving a much slower stage. This shows phenomena typical of a $2^{\text {nd }}$ - order kinetic model.The plotting of $\frac{C_{t}}{t}$ vs. time explained that phenomena. Fig. 3 shows the results of this analysis.

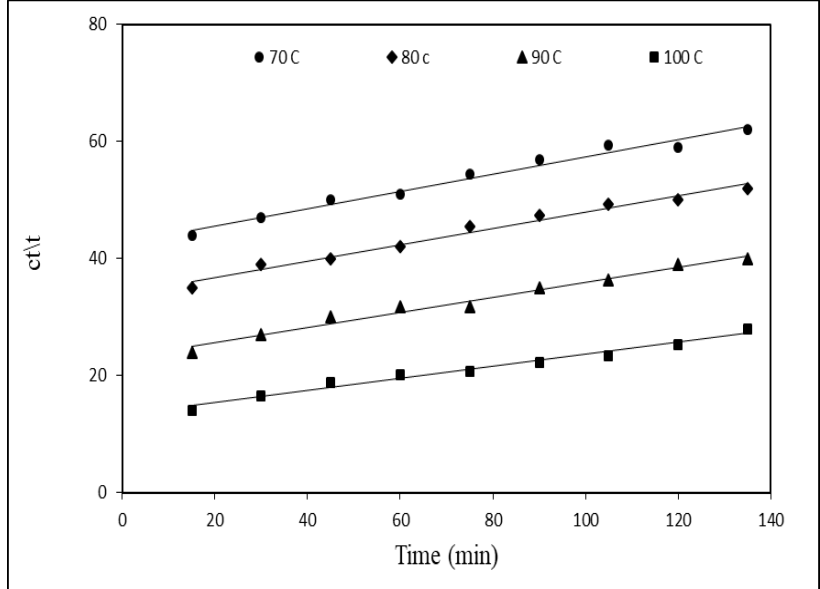

Fig. 3. Second-order extraction kinetics of EO in hydro distillation method from peppermint leaves at various temperatures

The amount of oil extracted increases rapidly with time at the beginning of the process. It decreases slowly with the time reaching the end of extraction process [10],[13],[19],[20],[21]. Equation (1) can be used to calculate the rate of extraction for the peppermint oil which is contained in the solid parts used.

The value of $\mathrm{k}_{\mathrm{r}}, \mathrm{CS}$, and hi, were determined through slope and intercept after linearization step as shown in Table 1.

Table 1. Parameters of the second-order kinetic model at various extraction temperatures of peppermint leaves by water

\begin{tabular}{cccc}
\hline $\operatorname{Temp}\left({ }^{0} \mathrm{C}\right)$ & $\begin{array}{c}\mathbf{C s} \\
\left(\mathbf{g ~ L}^{-\mathbf{1}}\right)\end{array}$ & $\begin{array}{c}\mathbf{k}_{\mathbf{r}} \\
\left(\mathbf{L g}^{-\mathbf{1}} \mathbf{m}^{\mathbf{1}}\right)\end{array}$ & $\begin{array}{c}\mathbf{h i} \\
\left(\mathbf{g ~ L}^{\mathbf{- 1}} \mathbf{m}^{-\mathbf{1}}\right)\end{array}$ \\
\hline 70 & 6.784 & 0.000509 & 0.023412 \\
80 & 7.189 & 0.000568 & 0.029371 \\
90 & 7.770 & 0.000717 & 0.043258 \\
100 & 9.660 & 0.000806 & 0.075212 \\
\hline
\end{tabular}

The initial rate of extraction, hi, increased with extraction temperature. Also, Cs and $\mathrm{k}_{\mathrm{r}}$, of $2^{\text {nd }}-$ order kinetic model behaved in the same manner. Moreover, from Fig.4 the capacity of extraction in the high temperature $\left(100{ }^{\circ} \mathrm{C}\right)$ was always superior to that the lower temperature $\left(70{ }^{\circ} \mathrm{C}\right)$. At the high temperature of extraction, the rate was faster than that at low temperature as can be seen in Fig.5 [22], [2].

However, at high temperature, the rat constant of extraction was higher than at low temperature.

The main reason for these results is that the cell penetration and diffusion are better in the high temperature [2]. 


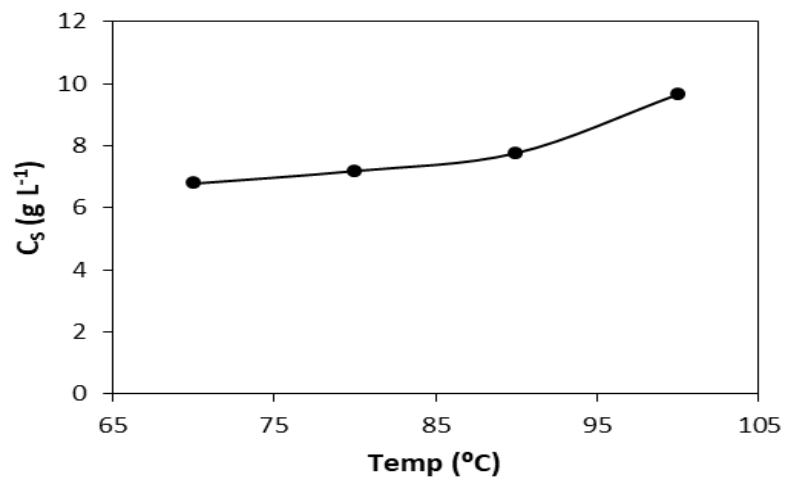

Fig. 4. Response of $\mathrm{Cs}$ by changing the extraction temperature

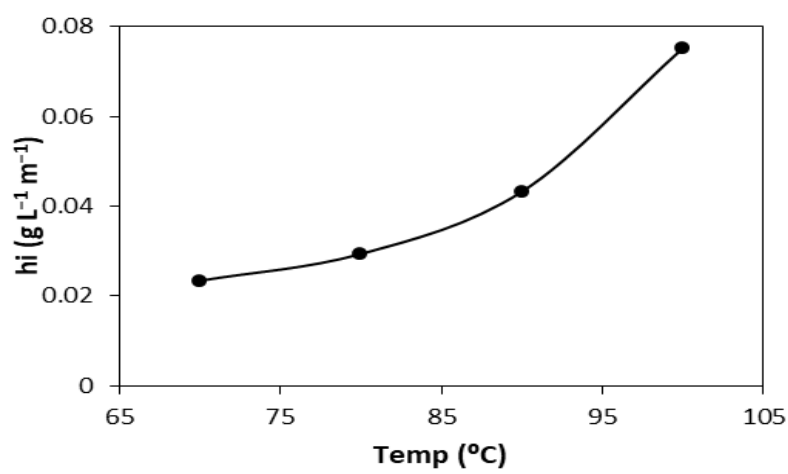

Fig. 5. Initial extraction rate (hi) at different temperature

\subsection{Activation energy}

The Arrhenius equation (9) obtained by plotting $\ln \mathrm{k}_{\mathrm{r}}$ versus1/T Fig. 6.

The plot of $\ln \left(\mathrm{k}_{\mathrm{r}}\right)$ vs. the reciprocal of the absolute temperature allows for calculating Arrhenius constant, A, and activation energy, $\mathrm{E}_{\mathrm{A}}$.

There was a linear relationship between $\ln \mathrm{k}_{\mathrm{r}}$ and $\frac{1}{\mathrm{~T}}$ with a determination coefficient of 0.9779. From Fig. 6, the Arrhenius constant, A, is $4.9126\left(\frac{\mathrm{L}}{\mathrm{g} \min }\right)$, and the activation energy for extraction, $\mathrm{E}_{\mathrm{A}}$, is $55.109\left(\frac{\mathrm{KJ}}{\mathrm{mol}}\right)$ showing that the extraction is an endothermic process.

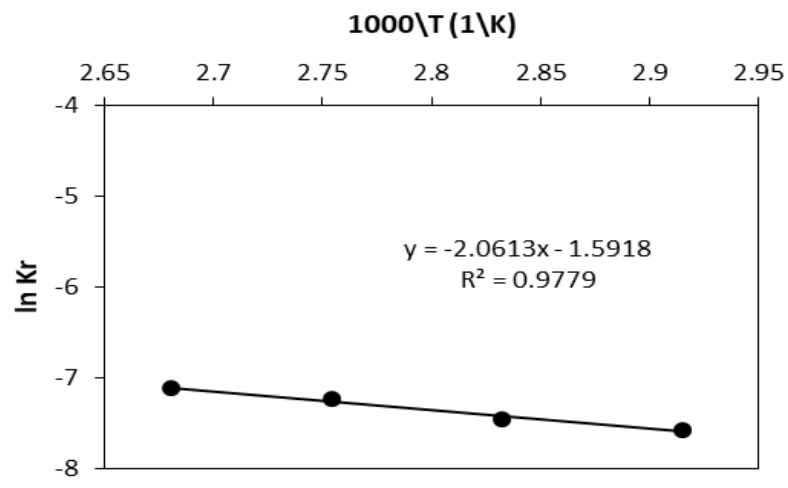

Fig. 6. Response of $\ln (\mathrm{k})$, vs. the reciprocal of the absolute temperature $(1 / \mathrm{T})$

\subsection{Thermodynamic Parameters}

Table 2 displays the values ofKe, $\Delta H, \Delta \mathrm{S}$ and $\Delta \mathrm{G}$ respectively at different temperature for the peppermint oil extraction process. While the plot of $\ln \mathrm{K}_{\mathrm{e}}$ verses the reciprocal of the absolute temperature $1 / \mathrm{T}$ that used to determine the value of thermodynamic parameters, is shown in Fig. 7.

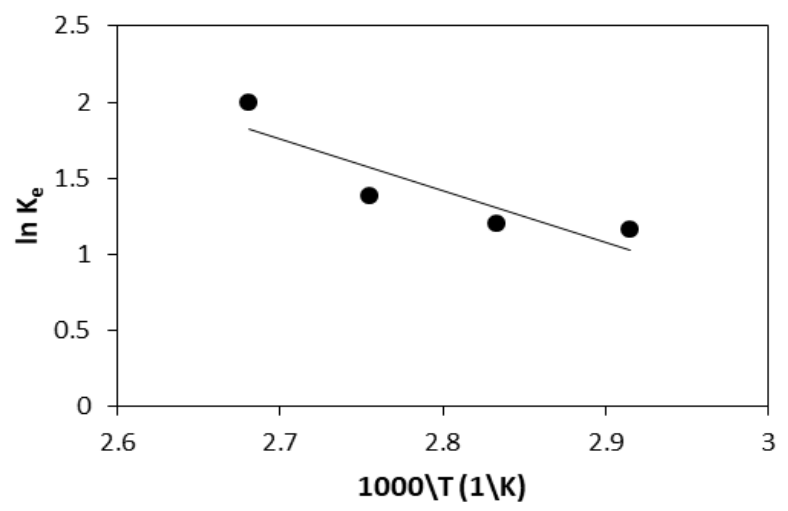

Fig. 7. Plotting of $\ln K_{e}$ vs. $1 / T$

Fig. 7 shows the linear dependence of $\ln K$ on the reciprocal of the absolute temperature, $1 / \mathrm{T}$, of the peppermint oil extraction. $\Delta \mathrm{H}$ and $\Delta \mathrm{S}$ were both estimated using the slope and intercept of the straight lines, respectively. The change in Gibbs free energy was found from $\Delta \mathrm{H}$ and $\Delta \mathrm{S}$ using equation (10). The values of $\Delta \mathrm{H}, \Delta \mathrm{S}$ and $\Delta \mathrm{G}$ are presented in Table 2.

Table 2. Thermodynamic parameters for extraction of peppermint oil

\begin{tabular}{ccccc}
\hline $\begin{array}{c}\text { Temp. } \\
\left({ }^{0} \mathrm{C}\right)\end{array}$ & $\begin{array}{c}\Delta \mathrm{H}^{0}(\mathrm{KJ} / \\
\mathrm{mo})\end{array}$ & $\begin{array}{c}\Delta \mathrm{S}^{0}(\mathrm{~J} / \mathrm{mol} \\
\mathrm{K})\end{array}$ & $\mathrm{K}_{\mathrm{e}}$ & $\Delta \mathrm{G}^{0}(\mathrm{~kJ} / \mathrm{mol})$ \\
\hline 70 & & & 3.19117 & -2.93 \\
80 & 28.247 & 90.905 & 3.30908 & -3.84 \\
90 & & & 4 & -4.75 \\
100 & & & 7.3408 & -5.66 \\
\hline
\end{tabular}

The value of $\Delta \mathrm{H}$ and $\Delta \mathrm{S}$ for the peppermint oil extraction were positive in the ranges of extraction temperature. Thus, this extraction process of the peppermint oil is shown to be both irreversible and endothermic.

The previous studies reported same results for the extraction of sunflowers oil [23], olive oil [15], soybeans oil [24], cottonseeds oil [25] and hempseed oil [26].The value of $\Delta \mathrm{H}$ gave the quantity of energy that the extraction process mixture; i.e., peppermint leave and water, should adsorb so that the peppermint oil extraction process can happen.

From Table 2, $\Delta \mathrm{G}$ was negative which shows that the extraction process of peppermint oil is favorable and spontaneous. The spontaneous nature of the extraction of the peppermint oil was favored with increase the extraction temperature. 


\section{4- Conclusion}

In this study, the kinetics of the EO extraction from peppermint leaves at different temperatures is based on a 2nd-order model. Consequently, it can be concluded that the mechanism of the EO extraction proceeds in two steps: a fast dissolution of peppermint oil followed by slow external diffusion of solute from the plant leaves.

Cs , $\mathrm{k}_{\mathrm{r}}$ and the hi can be predicted with this 2 nd-order model as a function of the temperature. In accordance with an endothermic process, the yield of peppermint oil is found to increase with extraction temperature.

The value of $\mathrm{E}_{\mathrm{A}}, 55.109\left(\frac{\mathrm{KJ}}{\mathrm{mol}}\right)$, showed that the extraction process is an irreversible and endothermic process. $\Delta \mathrm{G}^{0}$ shows that the extraction process of peppermint oil is favorable and spontaneous.

\section{References}

[1] Ouazzou A. A. ,Cherrat L., Espina L., Lorán S., Rota C., Pagán R., 2011. The antimicrobial activity of hydrophobic essential oil constituents acting alone or in combined processes of food preservation, Innovative Food Science and Emerging Technologies , 12(3): 320-329.

[2] Kusuma H. S. and Mahfud M., 2017. Microwave hydrodistillation for extraction of essential oil from PogostemoncablinBenth: Analysis and modelling of extraction kinetics, Journal of Applied Research on Medicinal and Aromatic Plants, 4:46-54.

[3] Burt S., 2004. "Essential oils: their antibacterial properties and potential applications in foods-a review, 94 (3): 223-253.

[4] Ali B., Al-Wabel N. A., Shams S., Ahamad A., Khan S. A., and Anwar F., 2015. Essential oils used in aromatherapy: A systemic review, Asian Pacific Journal of Tropical Biomedicine, 5( 8): pp. 601-611.

[5] Tavares A. C., Gonçalves M. J. , Cruz M. T., Cavalerio C., LopesM. C., Canhoto J. and Salgueiro L. R. , 2010.Essential oils from Distichoselinum tenuifolium: chemical composition, cytotoxicity, antifungal and anti-inflammatory properties, Journal of Ethnopharmacology, 130(3): 593-598.

[6] Abed K. M., Kurji B. M., and Abdulmajeed B. A.,2018.Extraction and Modelling of Oil from Eucalyptus camadulensis by Organic Solvent, Journal of Materials Science and Chemical Engineering, 2015(3): 35-42.

[7] Loolaie M., Moasefi N., Rasouli H., and Adibi H.,2017. Peppermint and its functionality: A review, Archive of Clinical Microbiology, 8(4): 1-16.

[8] Dai J., Orsat V., Raghavan G. V., and Yaylayan V., 2010. Investigation of various factors for the extraction of peppermint (Mentha piperita L.) leaves, Journal of Food Engineering, 96 (4): 540-543.

[9] Grigoleit H.-G. and GrigoleitP. , 2005. Gastrointestinal clinical pharmacology of peppermint oil, Phytomedicine, 12(8): 607-611.
[10] Gavahian M., Farahnaky A., Javidnia K., Majzoobi M. J. and Technologies E., 2012. Comparison of ohmic-assisted hydrodistillation with traditional hydrodistillation for the extraction of essential oils from Thymus vulgaris L, Innovative Food Science \& Emerging Technologies (14) : 85-91.

[11] Grigoleit H.-G. and Grigoleit P. J. P., 2005. Pharmacology and preclinical pharmacokinetics of peppermint oil, Phytomedicine, 12(8): 612-616.

[12] Jeyaratnam N., Nour A. H., Kanthasamy R., Nour A. H., Yuvaraj A. R. and Akindoyo J. O. ,2016. Essential oil from Cinnamomum cassia bark through hydrodistillation and advanced microwave assisted hydrodistillation, Industrial Crops and Products, 92: pp. 57-66.

[13] Rabesiaka L. R., Havet J. L., Porte C., Fauduet H., 2007. Solid-liquid extraction of protopine from Fumaria officinalis L.- analysis determination, kinetic reaction and model building, Separation and Purification Technology, 54(2): 253-261.

[14] Abdulraheem I. F., Al-Rubaye R. T., Abed K. M. and Abdulmajeed B. A., 2019. Extraction of jojba oil using various concentrations of two different solvents, Iraqi Journal of Agricultural Sciences, 50(4): under press.

[15] Eikani M. H., Golmohammad F., Homami S. S., 2012. Extraction of pomegranate (Punicagranatum L.) seed oil using superheated hexane, Food and Bioproducts Processing, 90(1): 32-36.

[16] Kusuma H. and Mahfud M., 2018. Kinetic studies on extraction of essential oil from sandalwood (Santalum album) by microwave air-hydrodistillation method, Alexandria Engineering Journal, 57(2): 1163-1172.

[17] Sulaiman S., Aziz A. A., and Aroua M. K., 2013. Optimization and modeling of extraction of solid coconut waste oil, Journal of Food Engineering, 114 (2): 228-234.

[18] Abed K. M. and Naife T. M., 2018. Extraction of Essential Oil from Iraqi Eucalyptus Camadulensis Leaves by Water Distillation Methods," in IOP Conference Series: Materials Science and Engineering, 454 (1): 012163: IOP Publishing.

[19] Ho Y.-S., Harouna-Oumarou H. A., Fauduet H. and Porte C. , 2005. Kinetics and model building of leaching of water-soluble compounds of Tilia sapwood, Separation and Purification Technology, 45(3):169-173.

[20] Meziane S. and Kadi H., 2008. Kinetics and thermodynamics of oil extraction from olive cake, $\mathrm{J}$ Am Oil Chem Soc, 85:391-396.

[21] Uhm J. T. and Yoon W. B., 2011. Effects of highpressure process on kinetics of leaching oil from soybean powder using hexane in batch systems, Journal of Food Science, 76(6): E444-E449.

[22] Abed K. M., Kurji B. M., and Abdulmajeed B. A.,2018. Extraction of Ocimumbasillicum Oil by Solvents Methods," Asian Journal of Chemistry, 30(5): 958-960. 
[23] Azmir J., Zaidul I. S. M., Rahman M. M., Sharif K. M., Mohamed A., Shahen F., Jahurul M. H. A., Ghafoor K., Norulaini N. A. and Omar A. K. M. ,2013. Techniques for extraction of bioactive compounds from plant materials: a review, Journal of Food Engineering, 117 (4): 426-436.

[24] Khasawneh R. F., 2017. Leaching of Jojoba Oil , Journal of Natural Sciences Research, 7(10): 49-62.
[25] TOPALLAR H. and GEÇGEL Ü., 2000. Kinetics and Thermodynamics of Oil Extraction from Sun ower Seeds in the Presence of Aqueous Acidic, Turkish Journal of Chemistry, 24(3): 247-254.

[26] Rodrigues C. E., Aracava K. K. and Abreu F. N., 2010. Thermodynamic and statistical analysis of soybean oil extraction process using renewable solvent, International Journal of Food Science and Technology, 45(11): 2407-2414.

\title{
دراسة حركيات وديناميكيات استخلاص زيت النعناع من اورلق النعناع
}

\author{
بدور محسن كرجي 1, خالدمحن عبد², سرمد عبدالرزاق رشيد². \\ ا قسم الهندسة الكيميائية و البتروكيميائية - كلية العنسة - جامعة الانبار - العراق

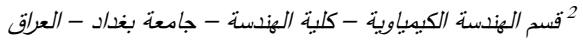

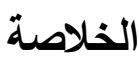

هذه الدراسة تهدف الى استخلاص الزيوت الطيارة من اوراق النعناع بطريقة التقطير المائي. استخلاص زيت النعناع بطريقة التقطير المائي درست تاثير درجة حرارة الاستخلاص على كمية الزيت المنتجة.

كذلك تم دراسة حركية التفاع لعملية الاستخلاص مـ بعد ذللك عملية التقطير المائي بالاعتماد على ميكانيكية

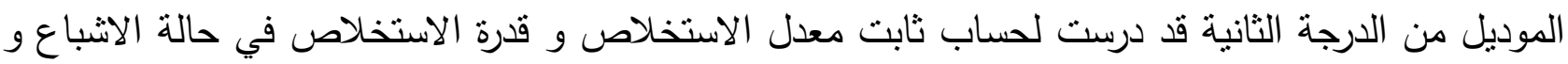

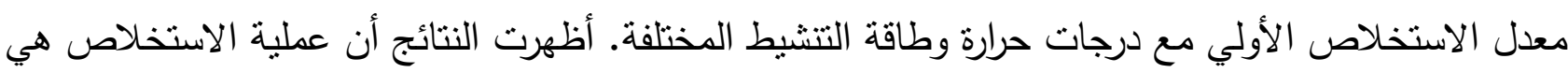
عملية تلقائية ، لأن طاقة جبس الحرة لها قيمة سالبة في جميع درجات الحرارة المدروسة. على سبيل المثال ،

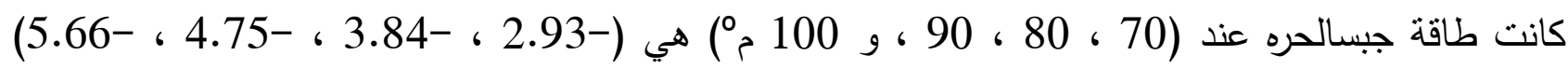

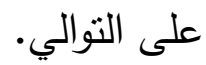

كلمات مفتاحية: التقطير المائي ، الاستخلاص ، معادلة أرينيوس ، تغيير الإنتروبيا ، التغير الحراري ، طاقة كبس الحره, ورق النعناع 